Revue des patrimoines

$41 \mid 2019$

Patrimoines gastronomiques. Définitions, typologies et enjeux de conservation

\title{
Le numéro en bref - Patrimoines gastronomiques : définitions, typologies et enjeux de conservation
}

The issue in brief - Gastronomic heritage: definitions, typologies and conservation issues

Marie-Hélène Bénetière, Isabelle Chave et Julie Faure et Michaël Vottero

\section{OpenEdition}

Journals

Édition électronique

URL : http://journals.openedition.org/insitu/26724

DOI : $10.4000 /$ insitu.26724

ISSN : $1630-7305$

Éditeur

Ministère de la Culture

Référence électronique

Marie-Hélène Bénetière, Isabelle Chave et Julie Faure et Michaël Vottero, « Le numéro en bref -

Patrimoines gastronomiques : définitions, typologies et enjeux de conservation », In Situ [En ligne], 41 |

2019, mis en ligne le 17 décembre 2019, consulté le 24 septembre 2020. URL : http://

journals.openedition.org/insitu/26724; DOI : https://doi.org/10.4000/insitu.26724

Ce document a été généré automatiquement le 24 septembre 2020.

\section{cc) (1) $९$}

In Situ Revues des patrimoines est mis à disposition selon les termes de la licence Creative Commons Attribution - Pas d'Utilisation Commerciale - Pas de Modification 4.0 International. 


\title{
Le numéro en bref - Patrimoines gastronomiques : définitions, typologies et enjeux de conservation
}

\author{
The issue in brief - Gastronomic heritage: definitions, typologies and \\ conservation issues
}

Marie-Hélène Bénetière, Isabelle Chave et Julie Faure et Michaël Vottero

Les contours du patrimoine gastronomique sont difficiles à cerner, d'où l'usage fréquent de l'expression au pluriel. À la fois matériel, immatériel et mémoriel, aux confins des champs de recherche de l'alimentation, de la botanique, de l'architecture, des arts décoratifs ou encore de la sociabilité, ce patrimoine protéiforme exige pour son étude la mobilisation de nombreuses disciplines scientifiques; il a renouvelé, au plan national et international, le regard des professionnels du patrimoine et des chercheurs et accéléré les collaborations interdisciplinaires.

2 Ce numéro d'In Situ. Revue des patrimoines consacré aux patrimoines gastronomiques a été préparé alors que l'inscription du repas gastronomique des Français sur la Liste représentative du patrimoine culturel immatériel de l'humanité fête son dixième anniversaire (novembre 2010). Depuis une décennie, en effet, cette reconnaissance internationale a fortement affirmé la dimension sociale, culturelle et patrimoniale de l'alimentation. Pourtant, quoique plébiscités, les patrimoines gastronomiques apparaissent à bien des égards menacés : uniformisation des productions et du goût, consommation de masse, monopoles industriels, pertes des savoir-faire artisanaux, absence de transmission des gestes et des techniques, normes réglementaires trop rigides, disparition des temps et des lieux de ces prises alimentaires festives, évolution des usages et des manières de table, typologies architecturales parfois peu regardées, éléments de mobilier méconnus ... 
C'est en envisageant le thème de la gastronomie comme un fait patrimonial qu'ont été rassemblées ces contributions de chercheurs en histoire ou en anthropologie, de professionnels du patrimoine et d'acteurs culturels issus du milieu associatif, avec le souhait de refléter toute la richesse et la diversité méthodologique suscitée par sa connaissance, sa préservation et sa valorisation scientifique et culturelle aujourd'hui. Les vingt-cinq articles de ce numéro s'organisent autour de trois axes de réflexion thématiques - les processus de patrimonialisation, les produits culinaires et les arts et manières de table -, complétés par un ensemble de témoignages.

4 The issue in brief - Gastronomic heritage: definitions, typologies and conservation issues

5 The contours of the gastronomic heritage are difficult to define, hence the frequent use of plural expression. At the same time tangible, intangible and memorable, at the borders of the research fields of food, botany, architecture, decorative arts and sociability, this protean heritage requires the mobilization of many scientific disciplines for its study; it has renewed, at the national and international level, the perspective of heritage professionals and researchers and accelerated interdisciplinary collaborations.

6 This issue of In Situ. Revue des patrimoines devoted to gastronomic heritage was prepared at the opening of the tenth anniversary of the inscription, in November 2010, of the French gastronomic meal on the Representative List of the Intangible Cultural Heritage of Humanity. Over the past decade, this international recognition has strongly affirmed the social, cultural and heritage dimension of food. However, although acclaimed, the gastronomic heritage appears in many respects threatened: standardization of production and taste, mass consumption, industrial monopolies, loss of artisanal knowhow, lack of transmission of gestures and techniques, rigid regulatory standards, disappearance of the times and places of these festive food intakes, changes in uses and table manners, architectural typologies that are sometimes overlooked, unknown furniture elements...

7 By considering the theme of gastronomy as a heritage fact, these contributions of researchers in history or anthropology, heritage professionals and cultural actors from the associative sector have been brought together, in order to reflect all the richness and methodological diversity generated by its knowledge, preservation and scientific and cultural value today. The twenty-five articles in this issue are organized around three thematic areas of reflection - patrimonialization processes, culinary products and table arts and manners -, complemented by a series of testimonies. 